\title{
Volviendo a los orígenes. La reconfiguración política- cultural del Partido Comunista de Chile y el rescate de los fundadores (1988-1990)*
}

\author{
Back to the origins. Political-cultural reconfiguration of the \\ Communist Party of Chile and the rescue of its founders (1988- \\ 1990)
}

\author{
Jorge Navarro López \\ Universidad de Santiago de Chile, \\ Comisión Nacional de Investigación Científica y Tecnológica, Chile \\ jorgenavarrolopez@gmail.com
}

\begin{abstract}
Resumen
Bajo el contexto de la disolución de los socialismos reales y la vuelta a la democracia en Chile, el PC buscó integrar nuevos referentes que le permitieran enfrentar el ambiente anticomunista de la época. Este trabajo analiza el contexto anticomunista chileno en víspera de la transición democrática y cómo este afectó la posición del PC. Asimismo, da cuenta de las respuestas que generó este partido al rescatar y conectar la historia del POS con la lucha por la democratización y la representación de los sectores populares en la década de 1990. La valoración positiva de la democracia que casi un siglo atrás había realizado el POS, les permitió a los comunistas reconfigurarse y encontrar un referente nacional que le ayudara a sobrevivir a la crisis del comunismo.
\end{abstract}

Palabras Clave

Partido Comunista de Chile; comunismo; transición democrática; anticomunismo; Partido Obrero Socialista

\footnotetext{
* Este artículo es producto del proyecto FONDECYT no 1150583 , donde me desempeño como ayudante de investigación. Agradezco las ideas y comentarios de Raquel Aranguez, José Ignacio Ponce, Fernando Pairicán y Rolando Álvarez.

Esta obra está sujeta a la Licencia Reconocimiento-NoComercial-CompartirIgual 4.0 Internacional de Creative Commons. http://creativecommons.org/licenses/by-nc-sa/4.0/ 
Volviendo a los orígenes. La reconfiguración política-cultural del Partido
Comunista de Chile y el rescate de los fundadores (1988-1990)

Abstract

In the context of the dissolution of real socialisms and Chile's return to democracy, the Communist Party (PC in Spanish and hereafter) sought new referents which would allow them to face the anti-communist atmosphere at the time. This article analyzes the Chilean anti-communist context in the eve of democratic transition and how it affected PC's position. It also gives an account of the responses which such party triggered by rescuing and connecting the Socialist Workers Party's (POS in Spanish and hereafter) history to the struggle for democratization and representation of popular sectors in the 1990s. The positive value given to democracy by POS almost a century before, allowed communists to reconfigure themselves and find a national referent to help them survive communism's crisis.

\section{Keywords}

Communist Party of Chile; communism; democratic transition; anti-communism; Socialist Workers Party

\section{Introducción}

En agosto de 1994 se puso fin a un nuevo Congreso del Partido Comunista de Chile (PC) que pasó a la historia como el XXo de esa colectividad. Lo llamativo es que este torneo había comenzado como el Xvıo congreso. Entre una y otra reunión la correlación histórica del PC se vio afectada. Claramente, no fue una corrección casual. Se trataba de una operación con fines políticos y culturales que buscaba hacer frente al declive de la tradición bolchevique que llevó a muchos partidos comunistas hacia la transformación, renovación, o más profundamente, a la desaparición. En esta coyuntura, el PC sumó cuatro congresos a su historia partidista, modificó y retrasó su año de fundación (de 1922 a 1912) e integró a su cultura política nuevos/viejos referentes, conceptos y símbolos, con la idea de enfrentar una realidad adversa que proclamaba a los cuatro vientos su disolución.

Este trabajo analiza el contexto sociopolítico que enfrentó el PC chileno en los primeros años de la transición democrática tras el fin de la dictadura cívicomilitar (1973-1990), conectándolo con los desafíos que significaron para este partido asumir el fin de la Guerra Fría y la reconfiguración de su cultura y política con la intención de mantener un papel significativo en el sistema institucional. Para algunos partidos comunistas, la crisis y disolución de los socialismos reales significó una crisis terminal. Para el PC chileno, fue un momento de intensa discusión interna, de transformaciones y cambios políticos y culturales. En este sentido, este artículo tiene por objeto, por una parte, insertarse en el debate histórico del comunismo en su momento de mayor crisis ${ }^{1} \mathrm{y}$, por otra, analizar la forma en que los comunistas chilenos enfrentaron políticamente dicha coyuntura crítica.

\footnotetext{
${ }^{1}$ La trayectoria del comunismo tras la crisis de la URSS y los socialismos reales, tiene importantes particularidades locales. Sobre el caso uruguayo, francés y español, véase respectivamente Adolfo Garcé, La política de la fe. Apogeo, crisis y reconstrucción del PCU (1985-2012), Montevideo, Editorial Fin de Siglo, 2012; Bernard Pudal, Un monde défait. Les communistes francais de 1956 à nos jours,

Bellecombe-en-Bauges, Éditions du Croquant, 2009; Luis Ramiro Fernández, Cambio y adaptación en la
} 
La trayectoria del PC en la transición ha sido un tema poco tratado por la historiografía. La investigación más relevante sobre el tema, plantea que gracias a su férreo dogmatismo el PC pudo subsistir a la crisis de los socialismos reales, quedando marginado políticamente y con una baja influencia en el país ${ }^{2}$. En cambio, en este trabajo propongo que el planteamiento sobre el dogmatismo comunista necesita ser revisado, pues, hacia el fin de la dictadura y comienzos de la transición el PC se embarcó en un proceso de redefinición política de la «democracia», influenciado por un contexto internacional y nacional adverso. Una de las respuestas del PC fue rescatar su propia historia. Para ello, recurrieron al Partido Obrero Socialista (POS), en el cual vieron elementos y prácticas que conectaron con su realidad contemporánea. La necesidad de restituir la lucha democrática como un elemento central de la política del PC, fue la clave desde donde se rescató la experiencia del POS (1912-1922) ${ }^{3}$.

Metodológicamente, hemos tomado en cuenta una parte de la historia de ambos partidos para entender el proceso de reconfiguración política y cultural que realizó el PC a comienzos de la transición democrática. En primer lugar, examinamos las particularidades de la transición chilena, en donde operaron factores internacionales (fin de la Guerra Fría y de los socialismos reales) y locales (anticomunismo y nuevas alianzas políticas). El ambiente político de la transición construyó una definición de democracia que excluía al PC, considerándolo como un actor disolvente en la coyuntura incluyente que proclamaba la «democracia de los acuerdos», es decir, el pacto de la élite política para terminar con la dictadura sin modificar las bases de su marco institucional ${ }^{4}$. En segundo lugar, se analizan los elementos con los cuales el PC fue reconstruyendo su discurso político haciendo referencia a la democracia, su principal bandera de lucha durante la dictadura. Como

izquierda. La evolución del Partido Comunista de España y de Izquierda Unida (1986-2000), Madrid, CIS-Siglo XXI, 2004; Manuel Bueno y Sergio Gálvez (Eds.), "Nosotros los comunistas”. Memoria, identidad e historia social, Madrid, FIM/Atrapasueños, 2009; Juan Andrade, El PCE y el PSOE en (la) transición. La evolución ideológica de la izquierda durante el proceso de cambio político, Madrid, Siglo XXI, 2012.

${ }^{2}$ Alfredo Riquelme, Rojo atardecer. El comunismo chileno entre dictadura y democracia, Santiago, DIBAM, 2009.

${ }^{3}$ En la «cultura política» del POS convergieron ideales, discursos, experiencias, rituales y símbolos que giraron en torno a la práctica anticapitalista y a la participación en las instituciones del sistema político a través de las elecciones. Una característica fundamental de su cultura política -y que tuvo continuidad en el PC- fue la representación de la democracia como una de las aspiraciones del socialismo y, también, como un medio político válido. Respecto a este tema, véase Jorge Navarro L., Revolucionarios y parlamentarios. La cultura política del Partido Obrero Socialista, 1912-1922, Santiago, Lom ediciones, 2017. Sobre las particularidades de este concepto y algunas reflexiones interesantes respecto a su uso historiográfico, véase Serge Bernstein, "La cultura política", en Jean-Pierre Rioux y Jean-François Sirinelli (dir.), Para una historia cultural, México D.F., Taurus, 1998, pp. 389-405; Rodrigo Patto Sá Motta, "Desafios e possibilidades na apropriação de cultura política pela historiografia", en Rodrigo Patto Sá Motta (dir.), Culturas Políticas na História: novos estudos, Belo Horizonte, Fino Traço Editora, 2009, pp. 13-37; y Manuel Pérez Ledesma e Ismael Saz C., "Presentación de la obra", en Miguel Ángel Cabrera y Juan Pro (coord.), La creación de las culturas políticas modernas, 1808-1933, Madrid-Zaragoza, Marcial Pons Historia-Prensas de la Universidad de Zaragoza, 2014, pp. 9-21.

${ }^{4}$ Sobre las características de la transición chilena, véase Manuel A. Garretón, La posibilidad democrática en Chile, Santiago, FLACSO, 1989 y el estudio introductorio de Paul Drake e Iván Jaksic (Comp.), El modelo chileno. Democracia y desarrollo en los noventa, Santiago, Lom Ediciones, 1999, pp. 11-38. 


\section{Volviendo a los orígenes. La reconfiguración política-cultural del Partido Comunista de Chile y el rescate de los fundadores (1988-1990)}

el POS fue una de sus principales referencias, volvemos hacia el momento en que este partido fue fundado (1912) para enfocarnos en su visión sobre la democracia y la política. Por último, realizamos un ejercicio comparativo entre las coyunturas adversas que vivieron ambos partidos y desde donde se comprende la intención del PC, mediante el ejemplo del POS, de reinterpretar su historia como una larga lucha por la democratización de la sociedad chilena.

\section{Chile en la década de 1990: anticomunismo, fin de la guerra fría y transición democrática}

La desestructuración de la URSS y del mundo socialista hacia fines de la década de 1980, significó un cataclismo que superó con creces las fronteras de Europa. El comunismo fue un fenómeno casi universal. Desde 1917 en adelante, allí donde el capitalismo fue afianzándose, también lo hicieron los partidos comunistas. Pero un día de noviembre de 1989, la caída del muro de Berlín marcó el inicio del fin de casi un siglo de una forma de hacer y comprender la política. La clausura de la «ilusión» comunista fue recibida fervorosamente por muchos ${ }^{5}$. Chile no fue la excepción.

La larga dictadura que gobernó a Chile (1973-1990) no fue, como pudiera creerse, la génesis del anticomunismo chileno. Huellas de este fenómeno son perceptibles a fines del siglo XIX, incluso cuando el comunismo no aparecía como un régimen político alternativo al liberalismo. Teniendo como base la triple matriz catolicismo-nacionalismo-liberalismo, el anticomunismo chileno operó política y culturalmente en la esfera pública. Con periodos de mayor y menor intensidad durante el siglo $\mathrm{xx}$, fue un imaginario social que permitió a quienes se identificaban con esta triple matriz construir un discurso y llevar a cabo acciones violentas (represiones populares y obreras, persecuciones a dirigentes, destrucción de imprentas de periódicos obreros, Ligas Patrióticas, etc.), bajo la convicción de que se enfrentaban a un mal que debía ser extirpado de la sociedad chilena. En este sentido, el anticomunismo chileno no fue una consecuencia directa de la Guerra Fría. Tan hondas serían sus raíces, que la dictadura militar de 1973-1990 representa sólo su corolario, operando al interior de ella una red de significados de larga duración, una «tradición anticomunista», profundamente autoritaria y activa políticamente6.

La revisión del escenario político chileno del periodo que va entre los últimos alientos de la dictadura y el inicio de la transición democrática confirma la

\footnotetext{
${ }^{5}$ François Furet, El pasado de una ilusión. Ensayo sobre la idea comunista en el siglo XX, México D. F., FCE, 1995.

${ }^{6}$ Marcelo Casals, La creación de la amenaza roja. Del surgimiento del anticomunismo en Chile a la «campaña del terror» de 1964, Santiago, Lom Ediciones, 2016. Sobre el anticomunismo en Brasil y Argentina, véase Rodrigo Patto Sá Motta, Em guarda contra o "perigo vermelho". O anticomunismo no Brasil (1917-1964), Sâo Paulo, Editora Perspectiva, 2002, y Mercedes F. López, "El anticomunismo argentino entre 1930 y 1943. Los orígenes de la construcción de un enemigo", The International Newsletter of Communist Studies, XXII-XXIII, 29-30, 2016-2017, pp. 71-80, respectivamente.
} 
profundidad histórica de la «tradición anticomunista». En el periodo previo a la transición democrática de los noventa los niveles de anticomunismo fueron lógicamente más intensos, debido a que la prensa y la casi totalidad de la esfera pública estaba dominada por los partidarios y funcionarios de la dictadura. Sin embargo, al contrario de lo que se podría llegar a creer, tras la relativa apertura política que posibilitó el plebiscito de 1988 no se verificó una moderación o desaparición de la beligerancia en contra de los comunistas.

Esto fue así, porque el PC no había sido un actor marginal de la lucha antidictatorial. Por el contrario, inclusive desde la marginalidad en que se encontraba a comienzos de los años ochenta, debido a la clandestinidad, represión y desaparición de muchos de sus más importantes dirigentes, el PC logró afianzarse como uno de los partidos con mayor capacidad de movilización. Su llamado al enfrentamiento directo con la dictadura se cristalizó teóricamente en la denominada Política de Rebelión Popular de Masas (PRPM) ${ }^{7}$ y prácticamente en la creación del Frente Patriótico Manuel Rodríguez (FPMR), su brazo armado.

El FPMR se creó a comienzos de la década del ochenta y en septiembre de 1986 no tuvo éxito en su intento de asesinar al líder de la dictadura militar, el Comandante en Jefe del Ejército, Gral. Augusto Pinochet ${ }^{8}$. Fue este hecho el que justamente marcaría la historia posterior del PC. A pesar del aislamiento que le generó la decisión de terminar la dictadura a través del asesinato de Pinochet, el PC continuó con la estrategia política de lograr la restitución de la antigua alianza de la izquierda marxista institucional. Sin embargo, existía un problema fundamental: sólo los comunistas y grupos marginales de militantes socialistas se consideraban todavía marxistas, el resto de los militantes de la izquierda institucional en el exilio había abandonado esta ideología y a fines de los ochenta se encontraban en un intenso proceso de renovación bajo las banderas de la socialdemocracia. A pesar de esto, la dirección comunista en el exilio intentó revivir los rescoldos políticos bajo la forma de una alianza anti-dictatorial de izquierda. Sin embargo, el camino a la transición había tomado su curso definitivo. En febrero de 1988 trece partidos entre los que se contaban los diversos grupos políticos en que se había dividido el Partido Socialista (PS)- tomaron la decisión de formar el Comando Nacional del NO para enfrentar el proceso plebiscitario definido por la dictadura. Esta instancia política constituyó la base de la futura Concertación de Partidos por la Democracia, que gobernó el país entre 1990 y 2010.

Este fracaso coyuntural no puede ser comprendido en su dimensión si no se tiene en cuenta lo que significó para el resto de la izquierda. No se trató sólo de una

\footnotetext{
${ }^{7}$ Para una interpretación y minuciosa reconstrucción del proceso de gestación de la PRPM, véase Rolando Álvarez V., “¿La noche del exilio? Los orígenes de la rebelión popular en el Partido Comunista de Chile”, en Verónica Valdivia, Rolando Álvarez y Julio Pinto, Su revolución contra nuestra revolución. Izquierdas y derechas en el Chile de Pinochet (1973-1981), Santiago, Lom Ediciones, 2006, pp. 101-152. ${ }^{8}$ Sobre el FPMR véase Luis Rojas N., De la rebelión popular a la sublevación imaginada. Antecedentes de la Historia Política y Militar del Partido Comunista de Chile y el FPMR, 1973-1990, Santiago, Lom Ediciones, 2011. Sobre los avatares del atentado y sus protagonistas, véase el interesante trabajo del periodista Juan Cristóbal Peña, Los fusileros. Crónica secreta de una guerrilla en Chile, Santiago, Random House Mondadori, 2013.
} 


\section{Volviendo a los orígenes. La reconfiguración política-cultural del Partido Comunista de Chile y el rescate de los fundadores (1988-1990)}

diferencia casual y momentánea, significó además el quiebre de la alianza política que había sido la base del gobierno de la Unidad Popular (1970-1973). Como lo plantea Luis Maira, uno de los principales intelectuales de la reunificación socialista, la decisión del PC de agudizar la lucha contra la dictadura mediante el uso de la violencia, sumado al fracaso del atentado a Pinochet y la posterior represión al movimiento social, socavaron las confianzas entre socialistas y comunistas. Según Maira, esas fueron las bases que sustentaron el giro de los socialistas hacia la Democracia Cristiana (DC), colectividad que tenía mayor margen de acción política en la esfera dictatorial ${ }^{9}$. Bajo esta mirada, el PC pasaría a ser el principal responsable de su marginación política en la transición.

Pero el panorama no está completo si no se entiende la coyuntura del término de la dictadura en donde se reordenó el mapa político. El fin de la Guerra Fría encontró a los comunistas en plena lucha por sobrevivir a los efectos de la dictadura y también a las consecuencias de la transición. Es decir, el aislamiento del PC no se explica sólo en los términos de Maira, también hay que prestar atención a un espacio mayor como la política internacional y, cómo no, a la tradición anticomunista chilena. La conjunción, en un periodo relativamente corto de tiempo, del colapso de los socialismos reales, de la transición democrática y del reordenamiento de las históricas alianzas políticas, entregan un cuadro más completo de la situación que enfrentaban los comunistas en la década del noventa. Las consecuencias de este proceso fueron de mayor alcance que el aislamiento del PC, también produjo un quiebre orgánico que afectó tanto al partido como a su juventud, crisis que si bien excede el tema de este trabajo, puede entenderse asimismo bajo el influjo de los tres factores antes mencionados ${ }^{10}$.

Si bien el PC había quedado al margen del bloque opositor en el plebiscito de octubre de 1988, de igual manera intentaba instalarse en la esfera política manifestando su intención de participar en las próximas elecciones parlamentarias. Tras su derrota en el plebiscito, la dictadura se mostró más permisiva respecto de la participación pública de los militantes tiempo atrás perseguidos, pero manteniendo aún la proscripción constitucional de los partidos marxistas por ser propagadores de lo que se entendía como «doctrinas que atenten contra la familia, propugnen la violencia o una concepción de sociedad, del Estado o del orden jurídico, de carácter totalitario o fundado en la lucha de clases» (artículo $8^{\circ}$ ). Por ello, frente a la posibilidad de formar un partido que representara abiertamente a la izquierda, pero sin una declaración de principios ideológica, los comunistas planteaban que su intención última era «avanzar a la democratización del país», es decir, «conquistar una democracia lo más profunda y avanzada posible, que permita la expresión más

\footnotetext{
${ }^{9}$ Luis Maira y Guido Vicario, Perspectivas de la izquierda latinoamericana. Seis diálogos, Santiago, FCE, 1991, pp. 94-102.

10 Un acercamiento y explicación de la crisis interna del PC en este periodo se puede encontrar en el trabajo aún inédito de Rolando Álvarez V., “¿Herejes y renegados?: la diáspora de la disidencia comunista chilena (1989-1994)" y en Fernando Pairicán P., "La gran crisis: las Juventudes Comunistas defendiendo la identidad en tiempos de transición y renovación democrática, 1989-1992", Izquierdas, 30, Octubre 2016, pp. 124-160.
} 
plena y soberana del pueblo y al mismo tiempo sea capaz de resolver los gravísimos problemas de la mayoría de los chilenos» ${ }^{11}$.

Pero el ambiente político, fuertemente influenciado por el anticomunismo, no estaba abierto a recibir positivamente estos gestos. Un efímero partido confusamente denominado Social Demócrata reconocía con estupor «el avance político y las acciones terroristas de los sectores revolucionarios que sólo buscan el enfrentamiento para establecer en Chile un régimen como el cubano». Fundaban este juicio en su apoyo a la dictadura en el plebiscito, lo que entendían como una demostración de su convicción democrática ${ }^{12}$. Similar postura expresaba una editorial del órgano oficial de la dictadura, La Nación, en la cual se llamaba a los partidos de oposición al aislamiento del PC por su casi genética propensión a los medios violentos, pues en esa colectividad no existía "tal "vocación democrática" [ya] que siempre ha utilizado simultáneamente la vía política y la violentista» ${ }^{13}$. El temor a los comunistas no era sólo expresado por los partidos políticos, alcanzaba también a diferentes movimiento sociales. A mediados de noviembre de 1988, la Federación Nacional de Estudiantes Secundarios denunciaba al PC de instrumentalizar y manipular a los estudiantes para que cometieran actos de violencia y con ello desestabilizar a la dictadura ${ }^{14}$.

La seducción comunista ha sido un tópico común en la historia del anticomunismo chileno. Si bien en el caso anterior hacía referencia a los estudiantes secundarios, también era utilizado para encarar las alianzas políticas que el PC impulsaba por aquellos días. En ese mismo mes, distintos grupos de izquierda lograron reunirse en el Partido Amplio de Izquierda Socialista (PAIS) -orgánica instrumental antes mencionada- que permitió a los comunistas participar de las elecciones de 1989. Frente a la virtual organización de la izquierda en un partido común, el futuro candidato presidencial derechista Joaquín Lavín (1999 y 2005) ${ }^{15}$, en un tono claramente anticomunista señalaba la urgencia de lograr la «unidad de los partidarios de la sociedad libre», que debía realizarse tras la figura de una «persona que esté imbuida de la modernización y transformación experimentada por Chile en los últimos años» ${ }^{16}$. Es decir, alguien identificado con la dictadura y con el modelo neoliberal. Un año después, el candidato presidencial de la «sociedad libre» lavinista fue el ex Ministro de Hacienda de Pinochet y uno de los principales articuladores de la modernización neoliberal, Hernán Büchi.

Pero no sólo la derecha planteaba la tesis de la seducción que ejercía el PC entre los actores políticos, desde las mismas filas de sus antiguos aliados socialistas se realizaban este tipo de acusaciones. Un dirigente de una de las fracciones en que

\footnotetext{
${ }^{11}$ La Nación, Santiago, 4/11/1988.

${ }^{12}$ La Nación, Santiago, 6/11/1988.

${ }^{13}$ La Nación, Santiago, 9/11/1988.

${ }^{14}$ La Nación, Santiago, 13/11/1988.

${ }^{15}$ Sobre los alcances y particularidades del «lavinismo» como estilo político sustentado en la lógica neoliberal y subsidiaria, véase Verónica Valdivia, "La derecha pinochetista en el post pinochetismo: auge y crisis del 'Lavinismo', 2000-2004”, Estudos Ibero-Americanos, v. 42, 2, maio-agosto 2016, pp. 694723.

${ }^{16}$ La Nación, Santiago, 21/11/1988.
} 


\section{Volviendo a los orígenes. La reconfiguración política-cultural del Partido Comunista de Chile y el rescate de los fundadores (1988-1990)}

había derivado la ruptura del PS, denunciaba que la formación del PAIS significaba la claudicación del histórico dirigente socialista, Clodomiro Almeyda, calificándolo para la ocasión como un «fiel servidor del PC [y] de la RDA»17. Esta crítica tenía como telón de fondo la reticencia del sector Almeyda -todavía cercano a la URSS- a la unificación socialista con los grupos renovados.

La figura del PC y el comunismo funcionaban como un repertorio discursivo que abarcaba horizontalmente a todo el ambiente político y verticalmente a diferentes organizaciones sociales. Estas características pueden conducirnos a pensar que se trataba de un fenómeno contextual, influenciado por el alto grado de represión y manipulación que ejercía todavía la dictadura. Sin embargo, la extensión del anticomunismo que se aprecia a fines de la década del ochenta es parte de un fenómeno de larga data, que más que nacer con el golpe de Estado de 1973 se vio reforzado por la propaganda (discursiva y práctica) que implementó la dictadura. Es en este sentido que entendemos la validez de la tesis de la historicidad del anticomunismo chileno ${ }^{18}$.

Más allá del temor que infundían -o quizás por lo mismo-, los comunistas fueron también el talismán que abrió la puerta a la configuración de la alianza política que gobernaría Chile por veinte años. Cuando el panorama de convergencia aún no era claro, el futuro primer presidente de la transición, el democratacristiano Patricio Aylwin, al establecer las bases mínimas para la existencia de la Concertación dejó en claro que el PC era la piedra de tope para cualquier alianza entre la oposición ${ }^{19}$. Respecto a este punto, el anteriormente mencionado Luis Maira -hasta ese momento presidente del PAIS- señala que, a pesar que los comunistas habían sido los principales promotores de la unidad de la oposición durante la primera década de la dictadura, hacia fines de los ochenta «si no estaba el PC todos los entendimientos eran posibles» ${ }^{20}$. Como lo expresa Maira, con la clausura decretada por la DC se sellaba la suerte de la inserción del PC en la política institucional chilena.

Enfrentado a un ambiente político adverso y con la intención de obtener representación parlamentaria en las elecciones de diciembre de 1989, el PC siguió adelante con su participación en el PAIS. Los ánimos de la oposición no eran favorables a la visualización comunista, incluso cuando éstos apoyaban abiertamente la opción del candidato de la Concertación, Patricio Aylwin. Cuando expresaron su intención de participar abiertamente en los actos políticos de dicha alianza, rápidamente surgieron voces contrarias, sobre todo en la DC. A pesar de esto, el PC declaraba compartir íntegramente la propuesta del presidente democratacristiano, Andrés Zaldívar, en cuanto a que el próximo gobierno democrático debía realizar el «desmantelamiento de la institucionalidad [de la dictadura]» 21 .

\footnotetext{
${ }^{17}$ La Nación, Santiago, 22/11/1988.

${ }^{18}$ Casals, op. cit.

${ }^{19}$ La Nación, Santiago, 24/11/1988.

${ }^{20}$ Maira y Vicario, op. cit., p. 134.

${ }^{21}$ La Nación, Santiago, 3/11/1989.
} 
Estos gestos no contribuyeron a disminuir el aislamiento político de los comunistas. Por su parte, la derecha pinochetista reaccionó manifestando su temor respecto al papel de la participación de los comunistas en un futuro gobierno de la Concertación. Según expresiones del ex embajador de la dictadura Sergio Diez, era claro que para el PC «la vía democrática es una etapa más para la conquista total del poder, la cual pasa por la lucha armada» ${ }^{22}$. Este tipo de opiniones tenían como propósito presentar la imagen de un PC que no se concordaba con su historia y menos aún con su actuación en la etapa previa del golpe de Estado de 1973. La estrategia de la derecha fue, en este sentido, resaltar la política insurreccional (PRPM) y su huella en la memoria reciente del país: comunistas armados, acciones violentas de desestabilización del régimen, discursos grandilocuentes y maniqueos. Como expresión de esto, durante noviembre de 1989 La Nación, bajo un discurso notoriamente anticomunista, destacó repetidamente el papel que le correspondía al PC en la violencia del periodo previo a las elecciones ${ }^{23}$. El mismo día de las sufragios, el periódico oficialista hizo un llamado a los votantes a evaluar «los valores que están en juego», resaltando la ligazón de Aylwin con «sectores manifiestamente antidemocráticos», es decir, con el PC. En esta línea, la editorial se preguntaba: «¿ha habido por parte del candidato presidencial izquierdista [sic] un categórico rechazo a lo aseverado por el líder máximo del comunismo y el más obcecado panegirista de Fidel Castro [es decir, Volodia Teitelboim], en cuanto a que su partido, sin perjuicio de apoyar "ahora" un eventual gobierno del señor Aylwin, "no abandonará su compromiso de promover la lucha armada y la rebelión de las masas"?»24.

Atacado desde diferentes frentes, el PC no logró revertir el ambiente anticomunista ni elegir parlamentarios en las elecciones de diciembre de 1989 . Y si bien consiguieron importantes votaciones en elecciones particulares, el escaso 4,2\% que alcanzó el PAIS fue expresivo del desfavorable momento en que se encontraban los comunistas. El triunfo del DC Patricio Aylwin, fortaleció el pacto político entre los ahora reunificados socialistas y el partido del nuevo presidente, lo que disminuyó aún más el rango de acción de los comunistas.

La derrota electoral del PC provocó una opinión favorable que fue transversal. Desde el ala más dura de la derecha, el ex Ministro del Interior de Pinochet y senador electo, Sergio Onofre Jarpa, expresó con regocijo que el «resultado que ha tenido el PC, donde ha quedado borrado del Congreso, es uno de los grandes éxitos de este régimen». En tanto, el futuro presidente Ricardo Lagos, a la vez que expresaba su intención de ponerse al servicio de Aylwin para «evitar desbordes que impliquen poner en peligro la transición», calificaba la derrota electoral comunista como un «voto castigo, por no compartir la ciudadanía buena parte de sus planteamientos» 25 . Esta idea del «voto castigo» fue ampliada por el

\footnotetext{
${ }^{22}$ La Nación, Santiago, 4/11/1989.

${ }^{23}$ Las editoriales que denunciaban la conexión del PC con las acciones violentas, por ejemplo, en $L a$ Nación, Santiago, 4, 8, 10, 11, 13, 20, 23 y 30/11/1989.

${ }^{24}$ La Nación, Santiago, 14/12/1989.

${ }^{25}$ La Nación, Santiago, 16/12/1989.
} 


\section{Volviendo a los orígenes. La reconfiguración política-cultural del Partido Comunista de Chile y el rescate de los fundadores (1988-1990)}

dirigente derechista Andrés Allamand, quien consideraba que la derrota del PC se explicaba más bien por «un desplazamiento del electorado hacia las posiciones de centro y una votación de castigo hacia las posiciones de izquierda» que por los efectos del sistema electoral binominal, mecanismo que era el principal objetivo de las criticas comunistas y de la izquierda en general ${ }^{26}$. En efecto, de haber existido un sistema proporcional el PC habría obtenido a lo menos dos diputados ${ }^{27}$. Frente a esta inapelable derrota, el Secretario General del PC, Volodia Teitelboim, proyectaba a futuro una línea política intermedia: no hacer oposición franca al nuevo gobierno e impulsar la «movilización de masas, la defensa activa del proceso democrático y el impulso a la ofensiva dirigida a destruir el poder fascista paralelo, apoyando y exigiendo el cumplimiento del programa y la democratización a fondo del país» ${ }^{28}$.

En los meses venideros el PC enfrentó un escenario desfavorable no solamente por sus resultados electorales, ni porque los pactos políticos post dictadura favorecieron a las colectividades que se comprometieron con la continuidad del modelo neoliberal, sino además porque su principal bastión de lucha durante casi dos décadas (el retorno a la democracia) figuraba ahora en las exitosas banderas de otras tiendas políticas. Estos mismos partidos - una buena parte de ellos sus anteriores aliados- destacaban la incapacidad de los comunistas para desarrollar una política «democrática», que en los códigos de la Concertación significaba actuar dentro del marco institucional heredado de la dictadura. Y, precisamente, la opción insurreccional que tomó el PC en el último cuarto del régimen de Pinochet no le permitía reconocer esta contextual lectura democrática. Entonces, ¿dónde buscar referentes políticos y culturales para fortalecer su oposición al legado de la dictadura?

\section{Democracia: del PC al POS y viceversa}

La actuación del PC bajo la orientación de la lucha armada en los últimos años de la dictadura no entregaba los elementos necesarios para sustentar una posición en el marco político institucional, principalmente por los efectos en la reconfiguración de la identidad partidaria que ésta significó, desplazando así su actuar desde una orientación sistémica, electoral y de masas hacia una perspectiva insurreccional ${ }^{29}$. Sumado a esto, las características del ambiente político chileno a comienzos de la transición democrática, proceso sustentado en las tesis del «fin de

\footnotetext{
${ }^{26}$ La Nación, Santiago, 19/12/1989. El sistema de elección parlamentaria binominal, aplicado por última vez en las elecciones del 2013, elegía por circunscripción a las primeras mayorías de las dos listas más votadas. A diferencia del sistema proporcional que elige a los candidatos con más votos, sin mediación de la suma de votos de las listas.

${ }^{27}$ Riquelme, op. cit., pp. 199-200.

${ }^{28}$ La Nación, Santiago, 20/12/1989.

${ }^{29}$ Rolando Álvarez V., Arriba los pobres del mundo. Cultura e identidad política del Partido Comunista de Chile entre democracia y dictadura. 1965-1990, Santiago, Lom Ediciones, 2011.
} 
la historia» ${ }^{30}$ y en la explicación de que la derrota de Pinochet había sido producto de un acuerdo entre la élite política, no dejaba espacio para otras interpretaciones de la democracia. Para contrarrestar esta situación, los comunistas se abocaron a la construcción de un nuevo repertorio político que con el tiempo se conoció como «Revolución Democrática». Esta tesis política buscaba destacar el rol histórico del PC, es decir, la labor realizada por este partido en la profundización democrática y en la representación política de los trabajadores desde comienzos del siglo XX. La figura del tipógrafo Luis Emilio Recabarren recobró así una posición primordial y una necesaria contemporaneidad. También lo hizo lo realizado por el POS entre 1912 y 1922.

1. La reconstrucción política y cultural de la democracia en el Partido Comunista

La disolución de los socialismos reales profundizó y dio sustento práctico al anticomunismo de fines de los ochenta, estrechando aún más el escenario político para el PC. La caída de la URSS fue interpretada como la demostración empírica de la superioridad de la democracia liberal y del capitalismo. Fue también un duro golpe para el movimiento comunista internacional, una derrota que llevó a muchos de aquellos que aún se «aferraban a la esperanza socialista original de construir una sociedad en nombre de la cooperación en lugar de la competitividad» a refugiarse en la «especulación y la teoría»31.

Si la abstracción teórica fue el camino de muchos en el mundo de la izquierda, la justificación histórica fue el lugar hacia donde se dirigieron los comunistas chilenos. Y para aquello contaban con figuras de peso. Su principal referente nacional hasta el golpe de Estado de 1973 había sido Recabarren, depositario de todas las virtudes del obrero comprometido con la organización clasista ${ }^{32}$. Hasta septiembre de 1973 el PC mantuvo un museo con su nombre, donde además de artefactos personales del dirigente se exhibían objetos que conectaban la historia del partido con la historia de los trabajadores del salitre. De su variopinta producción, Pablo Neruda nos legó un poema dedicado al dirigente. Conocida es también la canción con su nombre que compusiera Víctor Jara, una de las más destacadas figuras artísticas comunistas antes de la dictadura.

Recabarren ocupaba un lugar central en la cultura comunista. No son pocos los hijos de comunistas que llevan el nombre compuesto del dirigente o sólo Emilio. En las banderas era recurrente su imagen. Dentro de la imaginería comunista, Recabarren solía acompañar a Marx, Engels, Lenin y Stalin. Como señal del importante espacio que el PC otorgaba a la figura de Recabarren, Orlando Millas alto dirigente del partido hasta la década del ochenta- lo situó en un singular panteón de héroes nacionales, junto a personajes tan diversos como Bernardo

\footnotetext{
${ }^{30}$ Francis Fukuyama, “¿El fin de la historia?”, Estudios Públicos, 37, 1990, pp. 5-31.

${ }^{31}$ Eric Hobsbawm, Cómo cambiar el mundo, Buenos Aires, Crítica, 2013, p. 393.

32 Julio Pinto, Luis Emilio Recabarren. Una biografía histórica, Santiago, Lom Ediciones, 2013.
} 


\section{Volviendo a los orígenes. La reconfiguración política-cultural del Partido Comunista de Chile y el rescate de los fundadores (1988-1990)}

O’Higgins, Manuel Rodríguez, Diego Portales, Andrés Bello, José Manuel Balmaceda y Salvador Allende 33 .

Sin embargo, no ha sido siempre así. Hubo momentos donde su figura fue cuestionada, principalmente, por las particularidades de su ideología y práctica política. Esto se puso de manifiesto en la década de 1930, cuando en el contexto del proceso de bolchevización del PC la dirigencia del partido (y también la Internacional Comunista) criticó ácidamente el aporte de Recabarren, debido a su apego por las formas institucionales de hacer política ${ }^{34}$. Desde mediados del siglo XX, el legado de Recabarren fue disputado por el conjunto de la izquierda, lo que llevó a una batalla cultural entre los partidos ${ }^{35}$. En definitiva, lo que buscaban tanto los comunistas como la izquierda chilena previa a 1973, era reconocer en Recabarren el origen de una forma de hacer política, basada en la autonomía de la clase obrera, la organización de ésta en partido político y la búsqueda de la democratización y el socialismo.

Pero los comunistas de principios de los noventa vieron en Recabarren y en el POS algo más. Por una parte, ambas figuras significaban el reconocimiento de que la lucha obrera y socialista tenía, incluso antes de que se produjera la Revolución bolchevique, una matriz nacional. El historiador comunista Hernán Ramírez Necochea había hecho de este argumento una de las tesis principales de su ensayo sobre los primeros años de su partido. Sin embargo, en su trabajo el POS aparecía como una especie de prehistoria del $\mathrm{PC}^{36}$. En los noventa, en cambio, en el momento de mayor descrédito del movimiento comunista internacional, con la inminencia de la caída de la URSS y el desmoronamiento de los socialismos reales, el PC destacó aún más su carácter nacional y reflotó su directa conexión con la historia del POS.

En sus memorias, el anteriormente mencionado Orlando Millas destaca la «cordura» política de Recabarren, situándolo como el precursor de la lucha por la democracia y por el mejoramiento material de los sectores populares, de la cual reconocía en el PC a su legítimo heredero. Millas escribía desde su posición como un férreo opositor a la política militar de los ochenta, por ello enfatizaba el carácter de los comunistas como propiciadores de importantes alianzas políticas, como lo habían sido el Frente Popular (1936-1941) y la Unidad Popular en (1970-73). Quizás por lo mismo resaltaba la cultura política de los primeros años del PC, señalando que a diferencia de lo que ocurría en otras partes los comunistas chilenos «no era un grupo de sectarios que soñara con copiar el asalto al Palacio de Invierno, sino que era un partido decididamente proletario y de masas y con una efectiva democracia

\footnotetext{
${ }^{33}$ Orlando Millas, De O’Higgins a Allende. Páginas de la historia de Chile, Madrid, Ediciones Michay, s/f.

${ }^{34}$ Ximena Urtubia, Hegemonía y cultura política en el Partido Comunista de Chile: la transformación del militante tradicional, 1924-1933, Santiago, Ariadna Universitaria, 2016.

${ }^{35}$ Jaime Massardo, La formación del imaginario político Luis Emilio Recabarren, Santiago, Lom Ediciones, 2008, pp. 33-84.

${ }^{36}$ Hernán Ramírez N., Origen y formación del Partido Comunista de Chile,

Moscú, Editorial Progreso, 1984. Actualmente reeditada: Hernán Ramírez N., Obras escogidas vol. II, Santiago, Lom Ediciones, 2007.
} 
interna» ${ }^{37}$. La vinculación con el POS y Recabarren que Millas rescataba, estaba mediada por la defensa de una política que volviera a las masas y articulara alianzas que le permitieran al partido superar su aislamiento.

En una línea similar, los intelectuales comunistas de fines de los ochentas Augusto Samaniego y Álvaro Palacios destacaban la importancia de conjugar la democracia y el socialismo con las características específicas de la sociedad chilena. En esa línea, rescataban la experiencia de Recabarren como un ejemplo clave para resituar la «nacionalización» del marxismo y enfrentar el repliegue del socialismo a nivel mundial y nacional. En esta lectura, sostenían que la renovación del PC debía centrarse en la democratización de la sociedad post dictadura, sin perder la perspectiva del socialismo ${ }^{38}$.

El rescate de las raíces nacionales del PC era también el lugar desde donde Volodia Teitelboim evaluaba el contexto en que se encontraban los comunistas a comienzos de 1990. Para Teitelboim, la fundación del POS en 1912 significaba el comienzo de una larga lucha política, en la cual la transición democrática de los noventa constituía su etapa más contemporánea. Presentaba la historia del PC, llena de ilegalizaciones y clandestinidades, como el ejemplo más claro de su compromiso en la lucha por la democratización. Según su Secretario General, el PC debía tener como objetivo inmediato la restitución de un Estado democrático, al igual como lo habían hecho los fundadores del partido ${ }^{39}$.

Como vemos, tanto la historia de Recabarren como la del POS contenían un aspecto que resultaba significativo a la luz del fin de la dictadura y de los desafíos que el PC se planteaba para la transición. Desde que surgió en 1912, el POS tuvo como uno de sus objetivos primordiales la democratización de la sociedad. A comienzos del siglo Xx, el sistema político chileno tenía un sinnúmero de obstáculos que condicionaban la participación de los sectores populares. A fines del mismo siglo, la situación tenía tintes similares. El desmantelamiento del Estado, la pobreza generalizada y las trabas políticas legadas por la dictadura y recogidas por la Concertación, asomaban a los ojos comunistas como un buen momento para aprender de lo que habían hecho y experimentado los precursores del comunismo en Chile.

2. Volviendo el tiempo atrás: la fundación del Partido Obrero Socialista en $1912^{40}$

\footnotetext{
${ }^{37}$ Orlando Millas, Memorias, 1957-1991. Una digresión. Volumen IV, Santiago, Ediciones ChileAmérica CESOC, 1996, p. 338.

${ }^{38}$ Augusto Samaniego y Álvaro Palacios, "Pensando una "perestroika" para la izquierda chilena", en VV.AA., Crítica y socialismo: una reflexión desde Chile, Santiago, Ediciones CISPO, 1989, pp. 193-217. ${ }^{39}$ Volodia Teitelboim, "Democracia, socialismo y renovación del PC de Chile", en VV.AA., Crisis y renovación, Santiago, Ediciones Medusa-ICAL, 1990, pp. 203-231.

${ }^{40}$ Sobre la historia del POS véase los trabajos de Julio Pinto y Verónica Valdivia consignados en la bibliografía, además de Sergio Grez, Historia del Comunismo en Chile. La era de Recabarren (19121924), Santiago, Lom Ediciones, 2011 y Navarro L., op. cit.
} 
Volviendo a los orígenes. La reconfiguración política-cultural del Partido
Comunista de Chile y el rescate de los fundadores (1988-1990)

La primera interrogante que surge con la operación política del PC de volver a la tradición legada por el POS tiene que ver con cuáles eran los elementos y las prácticas que los comunistas creían necesarios rescatar de la experiencia de los obreros de comienzos del siglo xx. La respuesta conjuga factores externos a la organización, como la crisis del movimiento comunista internacional y el intenso anticomunismo que se generó en el contexto de la transición, e internos, como la crítica entre sus militantes al «centralismo democrático». Pero también hay que tomar en cuenta la reconfiguración y disputa de la democracia que a comienzos de los noventa se produjo en Chile. En este último sentido, la experiencia del POS entregaba claves para restituir la tradición de la lucha democrática como un aspecto central de la política del PC.

El POS surgió en 1912 de las bases del Partido Democrático (PD). Se fundó en la pampa salitrera de Iquique y se expandió al poco tiempo a Antofagasta, Santiago y Valparaíso, constituyéndose así en el primer partido netamente obrero del país. Este partido levantó bajo la bandera del socialismo las reivindicaciones de los trabajadores, con la idea de lograr reformas a través de la inserción en el sistema político. Como la oligarquía dominante no utilizaba únicamente al Estado como un aparato de represión, sino que también combinaba en él las acciones para ampliar y asentar su hegemonía, los socialistas comprendieron y utilizaron las posibilidades democráticas latentes que existían y, por ello, desarrollaron una estrategia políticainstitucional para cimentar el camino al socialismo. En este marco, los socialistas de la década de 1910 -al igual que los comunistas de los noventa- no se pusieron al margen de la situación política nacional.

Con la bandera del «socialismo» en una mano y la de la «democracia» en la otra, los fundadores del POS construyeron un discurso que les permitió ser a la vez revolucionarios y legitimadores del sistema político. Esta particular mixtura, los situó legítimamente en el centro del sistema al cual querían destruir, pero dentro del cual promovían la participación obrera. Comprendían la democracia como el ideal que sintetizaba los valores socialistas y se la identificaba con la ejecución de propósitos como la igualdad, la realización plena del individuo y la justicia social.

De manera práctica también, la búsqueda del socialismo del POS implicaba el uso de la democracia como medio de acción política. Así, entre los medios para llegar al socialismo estaba la lucha política a través de las acciones del partido y la participación en las elecciones, pero también la lucha económica, mediante las huelgas y las cooperativas. En este sentido, la fórmula socialista presentaba aspectos novedosos sobre la concepción democrática, ya que iba más allá de la dimensión procedimental y formal de la igualdad en el voto. Desde su fundación el POS entendió la participación en las elecciones como un deber de los trabajadores. Un deber ético que implicaba a la vez el saneamiento de la actividad política, fundamentalmente por los efectos que tenía la compra-venta de votos en las elecciones de representación popular.

La instalación del POS en el escenario político de comienzos del siglo Xx fue compleja. Con su creación se expresaron tensiones que se desprendían de la propia 
formación e inserción sistémica de un partido político de carácter clasista y anticapitalista. En sus primeras acciones, los socialistas buscaron separar aguas en materia política tanto de la oligarquía como de sus adversarios en el mundo obrero. Si bien el PD se había planteado desde fines del siglo XIX representar y canalizar los intereses populares en las instituciones estatales, hacia 1912 este partido se encontraba sumergido en alianzas que desconocían las diferencias ideológicas con fines electorales y participaban activamente en la compra-venta de votos ${ }^{41}$. Por otro lado, los anarquistas rechazaban los medios "políticos», bajo una propuesta de enfrentamiento directo con los capitalistas y el Estado. Así, con la valoración positiva de la democracia y de la acción obrera en la política institucional a través de un partido, los socialistas se diferenciaban de los sectores dominantes y de la utilización de la política como herramienta para los negocios personales, de los demócratas, cada vez más insertos en una acción política alejada de los sectores populares, y también de los anarquistas y su negación de la política institucional ${ }^{42}$.

Desde la fundación del POS en Iquique a mediados de 1912, la participación en la institucionalidad política a través de la competencia por los cargos de representación fue defendida desmarcándose de la forma de hacer política tanto de los partidos oligárquicos como del PD. Todos estos eran comprendidos como parte de los «partidos históricos», es decir, como segmentos de los sectores dominantes. Por ello, las acciones del POS estuvieron marcadas por un distanciamiento práctico y discursivo de esa forma de hacer política, justificándose en la búsqueda de una democracia plena que reconociera los intereses de los trabajadores y se encaminara a la construcción de una sociedad socialista.

3. De vuelta al presente: acomodándose a los términos de la transición

Teniendo en cuenta las características esbozadas en el apartado anterior, no es fortuito que dos investigadores ligados al PC realizaran en 1992 un estudio monográfico sobre la historia del POS entre 1912 y 1915, es decir, desde su fundación hasta su primer congreso. Su objetivo era acercarse al contenido de los conceptos utilizados por los obreros que fundaron el POS, con la finalidad de dar cuenta del imaginario político que estaba detrás de su proyecto de transformación social. Este trabajo puede ser visto como un producto de la búsqueda de referentes en que se embarcó el PC a comienzos de los noventa. En este sentido, el subtítulo que llevaba es sintomático: «Reconstruyendo un proyecto histórico-social» ${ }^{43}$.

\footnotetext{
${ }^{41}$ Sergio Grez, El Partido Democrático de Chile. Auge y ocaso de una organización política popular (1887-1927), Santiago, Lom Ediciones, 2016.

42 Navarro L., op. cit., pp. 33-59.

${ }^{43}$ Claudia Aranda y Ricardo Canales, Fundamentos históricos e ideológicos del Partido Obrero Socialista de Chile (1912-1915), Mimeo, 1992. Agradezco la noticia y el acceso a este trabajo a la historiadora Raquel Aranguez, quien ha realizado una importante labor heurística sobre la documentación comunista del período post dictadura.
} 
Volviendo a los orígenes. La reconfiguración política-cultural del Partido
Comunista de Chile y el rescate de los fundadores (1988-1990)

¿Qué proyecto histórico-social entreveían los comunistas de los noventa que era necesario conocer? Un proyecto democratizador que se enfrentara a los enclaves autoritarios presentes en la Constitución Política promulgada por la dictadura en 1980 y que hacia fines de esa década parecía legitimarse en la «democracia de los acuerdos». Era todavía el inicio de un nuevo camino para el PC. En septiembre de 1989, se leía en una editorial del órgano oficial comunista El Siglo su intención de «lograr que las amplias fuerzas democráticas alcancen en la batalla electoral de diciembre, un triunfo contundente que permita dotar al país de un Presidente y de un Parlamento con significativa representación popular» ${ }^{44}$. Era una declaración en el contexto de la alianza electoral que dio origen al efímero PAIS. En cambio, unos meses después, el Comité Central más cauto y con los resultados de las elecciones sobre la mesa advertía el problemático despliegue que tendría el gobierno de Aylwin debido a los efectos de un Parlamento virtualmente empatado, lo que en consecuencia significaría que el «tránsito democrático se verá seriamente dificultado». La declaración agregaba además la importancia que debían tener las organizaciones sociales «del pueblo para afianzar el gran triunfo alcanzado, ayudar a la consolidación y defensa del gobierno de Aylwin, al cumplimiento de su programa, al profundo proceso de democratización de toda la vida nacional»45. Se trataba de una declaración que aún tenía confianza en las reformas prometidas por la Concertación.

Las esperanzas que albergaban los comunistas en el cambio de gobierno rápidamente se fueron diluyendo. Todavía situado en el marco de la fundación del partido en 1922, el PC celebró su 68o aniversario a comienzos de enero de 1990. En esta multitudinaria celebración se observaron importantes cambios. Uno de tipo simbólico fue la renovación del emblema de la hoz y el martillo clásico -es decir, bolchevizada-, por otro de brocha gorda diseñado por el pintor José Balmes. El PC comenzaba a chilenizarse. El discurso principal de aquel día estuvo a cargo de Volodia Teitelboim, quien hizo notar que esa jornada pudo haber sido la celebración del 78 - aniversario, "si aceptáramos con bastante respeto por la historia, que nuestra organización nació como Partido Obrero Socialista en 1912». Se daba un paso.

Aclaraba más adelante que la idea de socialismo que sustentaba el PC no «será copia de nada, ni de nadie», agregando que su partido desde «su fundación ha sido tan democrático y tan libertario que nadie podrá señalar nunca el más leve desliz o guiño de complicidad con golpes de Estado o amenazas a la democracia», frases que acompañó con la autocrítica partidista por haber caído en el «mito de Stalin». Al definir las tareas inmediatas de los comunistas, planteaba que la más importante debía ser el «desmontaje de la estructura fascista», lo que implicaba dejar atrás las prácticas y discursos de la PRPM, volcarse «hacia las masas y trabajar sin descanso en los organismos sociales, destinados desde ahora a convertirse en

\footnotetext{
${ }^{44}$ El Siglo, Santiago, 18/09/1989.

${ }^{45}$ El Siglo, Santiago, 25/12/1989. Citado en Riquelme, op. cit., pp. 201-202.
} 


\section{Jorge Navarro López}

escenarios democráticos fundamentales de la acción del pueblo». Este despliegue debía verificarse en las organizaciones de trabajadores, pobladores, feministas, estudiantes, jóvenes, pensionados, pequeños y medianos comerciantes, profesionales, universitarios e intelectuales, es decir, todo el «universo democrático [que] tiene que ponerse en movimiento para apoyar las demandas justas del pueblo y de la nación». Estas demandas debían a lo menos cristalizarse en un cambio de modelo político y económico. El concepto democrático de los comunistas expresado en las palabras de Teitelboim se apoyaba en un proceso que debía nacer desde las bases, en el cual el PC ponía sus esperanzas para que la democratización no fuera sólo entendida como participación electoral y para que, en definitiva, en Chile se estructurase una «sociedad auténticamente democrática» 46 .

Una semana después en un masivo acto, la importante dirigente comunista Gladys Marín -en su reaparición pública luego de más de una década de clandestinidad- destacó nuevamente el papel jugado por el PC en la reconstrucción democrática. En un tono más crítico que Teitelboim, Marín enfatizó en el carácter continuista que podía alcanzar la transición, frente a lo cual se debía comprender que la democracia era más profunda que el acto de votar en las elecciones, reiterando la aspiración de alcanzar una «democratización a fondo de la sociedad». A contrapelo de la renovación que experimentaba gran parte de la izquierda, pero también de las formas de hacer política de los comunistas del período previo, Marín planteaba que el PC estaba «decididamente por la renovación, renovación no restringida al Partido, sino a la sociedad, a conceptos, a métodos nuevos de hacer política, a establecer relaciones más profundas, más directas con la gente» ${ }^{47}$. A lo largo del discurso de Marín la democracia tuvo una interpretación amplia, algunas veces su invocación se orientaba hacia al conflicto interno del PC (críticas al «centralismo democrático»), otras refiriéndose al proceso que vivía el país.

Por aquellos meses de verano, el dirigente Oscar Azócar ampliaba el concepto de democracia que buscaba el PC, relacionándolo ahora con el de revolución. Aún más escéptico que Marín sostenía que la «"transición pactada" [...] no dará solución a los problemas más urgentes de las grandes mayorías», porque la Concertación carecía de una orientación para la profundización de las reformas económicas, sociales y políticas. Esta opinión, según declaraba, se basaba todavía en la PRPM, ya no comprendida como enfrentamiento militar sino como la agudización de la movilización popular y de la lucha democrática ${ }^{48}$.

El discurso comunista se iba amoldando a la realidad política que vivía el país, por lo mismo se iba reconfigurando y profundizaba en ciertas materias. En marzo de 1990, el dirigente comunista Jorge Insunza manifestaba -ante la inminencia de la legalización de su partido- que no se someterían «jamás a la legalidad impuesta por el fascismo», ante lo cual seguían planteando «como condición indispensable para la democracia en Chile la ruptura del sistema institucional que ha impuesto Pinochet».

\footnotetext{
${ }^{46}$ El Siglo, Santiago, 8/01/1990.

${ }^{47}$ Pluma y Pincel, Santiago, 18/01/1990.

${ }^{48}$ Pluma y Pincel, Santiago, 1/02/1990.
} 


\section{Volviendo a los orígenes. La reconfiguración política-cultural del Partido Comunista de Chile y el rescate de los fundadores (1988-1990)}

Sostenía, además, que frente al gobierno de la Concertación el PC tendría «una actitud claramente crítica ante aquellas cosas que no conduzcan efectivamente a la democracia» ${ }^{49}$. Era el inicio de lo que se conocería como «independencia crítica», postura que se iría profundizando con el correr de los meses.

En estas declaraciones vemos que la disputa de la democracia fue ahondándose con la puesta en marcha del gobierno de Aylwin y con la percepción, primero, y la constatación, después, del mantenimiento de la institucionalidad de la dictadura. Aunque el PC había quedado fuera del Parlamento por el efecto de las leyes electorales, muchos comunistas (y en mayor grado los ex comunistas) aún creían que la Concertación realizaría los ajustes necesarios para ampliar la democratización. Las opiniones de sus dirigentes expresan que para los comunistas el concepto de democracia no era unívoco y que de su discusión y definición se derivaban posibles líneas de acción y de pensamiento.

Poco contribuyó a generar confianza en un posible cambio de rumbo el asesinato a manos de la policía del militante comunista Osmán Yoemans Osorio, mientras pintaba un mural que conmemoraba el natalicio de Salvador Allende ${ }^{50}$. La democracia había llegado, pero de manera dramática se demostraba que su arribo sería sin el desmantelamiento del aparataje legal de la dictadura, ni tampoco de las prácticas de represión. ¿Los comunistas y las demás fuerzas políticas hablaban de la misma democracia?

El anticomunismo, el quiebre de la alianza histórica de la izquierda, la marginación del PC del Parlamento y la continuidad del sistema impuesto por la dictadura, condujeron a los comunistas a redefinir su discurso político. Era evidente que la radicalización del movimiento popular no había logrado el quiebre de la dictadura, ni que la movilización que implicó el plebiscito y las elecciones tendrían una continuidad en un esfuerzo democratizador mayor. Diecisiete años de dictadura, de represión, persecución y miedo, habían agotado las bases de la movilización de masas. Además, el exitismo que generaba el nuevo tipo de consumo comenzaba a asentarse en la cultura chilena ${ }^{51}$. Y en un ambiente donde desde distintos planos se llamaba a la desaparición del PC, este decidió renovarse. Una renovación que en la práctica ya había significado dejar atrás la política insurreccional.

Se trataba de una renovación que se proyectaba a futuro pero mirando al pasado. En esta línea, la Conferencia Nacional comunista de junio de 1990 señalaba que, dadas las circunstancias por las que atravesaba el PC, tenía «sentido retornar a nuestras entrañables raíces históricas y [...] reconocer como fecha de nacimiento de nuestra organización el 4 de junio de 1912, cuando Luis Emilio Recabarren fundó en Iquique el Partido Obrero Socialista». Esta proposición se basaba en la necesidad de que el PC debía «hacer una contribución decisiva a la democratización del país en

\footnotetext{
49 Pluma y Pincel, Santiago, 8/03/1990.

${ }^{50}$ El Siglo, Santiago, 1/06/1990.

${ }^{51}$ Sobre las formas y efectos del consumo tras los cambios institucionales de la dictadura, véase Tomás Moulian, Chile actual. Anatomía de un mito, Santiago, Lom Ediciones, 1997, pp. 83-122.
} 
todas las áreas», en la idea de erigirse como el «arquitecto infatigable de la convergencia de las fuerzas democráticas, de la recomposición de la izquierda» ${ }^{52}$. Se daba un paso fundamental de una iniciativa que tendría como resultado la tesis política de la «Revolución Democrática» del congreso de 1994.

¿Qué vieron los comunistas de fines del siglo XX que fuera digno de destacar en la figura de Recabarren y en la actuación del POS? ¿Cómo se relacionaba el rescate de ese legado con la situación política de Chile pos-dictatorial?

\section{El POS y el PC: un ejercicio comparativo}

A partir de lo expuesto hasta aquí, creo que se puede comprender el interés de los comunistas por reflotar la tradición del POS. A riesgo de comparar procesos históricos diferentes, bosquejaremos algunos puntos para exponer cuáles eran los elementos que permiten explicar el interés de los comunistas por reflotar la tradición del POS.

Las condiciones que experimentaron ambos partidos pueden asimilarse teniendo en cuenta la exclusión que denunciaban tanto los socialistas en 1912 como los comunistas en 1990. Sin duda, ambas situaciones políticas sólo pueden ser comparables desde el punto de vista de la percepción de los actores. La exclusión formaba parte de ambos escenarios políticos a pesar de ser políticamente tolerantes. Como ha planteado Casals, el anticomunismo chileno no es un fenómeno derivado de la Guerra Fría, sino que tiene raíces que se hunden profundamente, lo que permite conectar la historia del POS con la del PC. En este sentido, ambos partidos se sentían injustamente excluidos del sistema político y, más importante aún, comprendían que eran las reivindicaciones populares las que no tenían eco entre los gobernantes.

Respecto a la represión del movimiento popular de comienzos del siglo Xx, Pablo Artaza ha planteado que el ambiente represivo tras la matanza obrera de la Escuela Santa María de Iquique, en diciembre de 1907, incidió negativamente en la legitimidad de las huelgas y positivamente en la valoración de la acción política sistémica ${ }^{53}$. Este último aspecto es evidente entre los socialistas, quienes resaltaban constantemente las consecuencias negativas que podía tener la radicalidad de algunos movimientos huelguísticos. Los comunistas al cerrar las puertas a la insurrección armada contra la dictadura, optaron por encauzar sus reivindicaciones a través de los mecanismos institucionales existentes a fines de la década de los ochenta. Tanto para ellos como para los militantes del POS, la acción política institucional no era ajena. Para los socialistas, el recurso de la violencia no formó

\footnotetext{
52 "Conferencia Nacional del Partido Comunista de Chile", Mimeo, junio 1990, p. 49.

${ }^{53}$ Pablo Artaza, Movimiento social y politización popular en Tarapacá. 1900-1912, Concepción, Ediciones Escaparate, 2006.
} 


\section{Volviendo a los orígenes. La reconfiguración política-cultural del Partido Comunista de Chile y el rescate de los fundadores (1988-1990)}

parte de su repertorio político ${ }^{54}$. Para los comunistas, su etapa insurreccional significó un quiebre en la identidad partidaria (de masas, legalista, electoral) y fue fuente de discordia entre los militantes ${ }^{55}$. En este punto, la tradición sistémica que el PC heredó del POS es innegable y tuvo continuidad por casi un siglo.

Como el POS surgió cinco años antes de que los bolcheviques se hicieran con el poder en Rusia, los comunistas veían en ello la posibilidad de salvar las tan cuestionadas raíces soviéticas del comunismo. El recurso retórico del «oro de Moscú» o la broma de que cuando llovía en la capital de la URSS los comunistas chilenos abrían sus paraguas, no eran sólo frases de sentido común, sino que operaban política y, quizás más importante aún, culturalmente en el Chile de la segunda mitad del siglo Xx. Sin embargo, la realidad histórica fue otra. No sólo el PC tuvo que hacerse cargo de este tipo de acusaciones. Desde que el POS surgió, el ambiente político de la época cuestionó su carácter endógeno. Como en otras partes del mundo, las organizaciones de comienzos del siglo xx ligadas al socialismo (socialistas o anarquistas) fueron denunciadas como obras de agentes extranjeros disociadores. Frente a este tipo de acusaciones el POS siempre defendió su carácter nacional y persistió en su acción política a pesar de la represión estatal y paraestatal, como las Ligas Patrióticas ${ }^{56}$. En igual medida lo hicieron los comunistas desde la década del veinte ${ }^{57}$ hasta la del noventa, teniendo que coexistir con leyes de exclusión política, encarcelamientos y golpes de Estado. A pesar de todas estas acusaciones y persecuciones, ambas organizaciones siempre reafirmaron su internacionalismo obrero.

Las distintas versiones de democracia que circulaban en el ambiente político de los ochenta y noventa, dan cuenta de que no se trataba de un concepto estático ni que sólo describiera a un procedimiento electoral, visión que era compartida por socialistas y comunistas. Para el POS la redefinición de la democracia fue su punto de partida en el sistema político formal. Desde un primer momento, esta estuvo estrechamente ligada a su concepción de socialismo. Para ese partido era una aspiración ética y política que sólo podía lograrse bajo el gran paraguas del socialismo ${ }^{58}$. Como hemos visto, el PC no difería mucho de esta noción. Ambos partidos sostenían que la democracia debía fundarse en la participación y discusión

\footnotetext{
${ }^{54} \mathrm{Si}$ bien los socialistas fueron discursiva y prácticamente contrarios al uso de métodos violentos, en algunas ocasiones sus militantes recurrieron a ellas. Un ejemplo de esto, fue el movimiento previo a la matanza obrera de la oficina salitrera San Gregorio en 1921. Véase Floreal Recabarren, La matanza de San Gregorio. 1921: crisis y tragedia, Lom Ediciones, 2003.

55 Álvarez, Arriba los pobres del mundo, op. cit.

${ }^{56}$ Sergio González M., Carlos Maldonado y Sandra McGee, "Las Ligas Patrióticas”, Revista de Ciencias Sociales, 2, 1993, pp. 54-72. Sobre la persecución de los anarquistas bajo este discurso nacionalista véase Víctor Muñoz C., Cuando la patria mata. La historia del anarquista Julio Rebosio (1914-1920), Santiago, Editorial USACH, 2011 y Camilo Plaza A. y Víctor Muñoz C., "La Ley de Residencia de 1918 y la persecución a los extranjeros subversivos", Revista de Derechos Fundamentales, 10, 2013, pp. 107136.

${ }^{57}$ Rolando Álvarez, “ ¡Viva la revolución y la patria! Partido Comunista de Chile y nacionalismo (19211926)", Revista de Historia Social y de las mentalidades, 7, vol. 2, 2003, pp. 25-44.

${ }^{58}$ Navarro L., op. cit., pp. 33-46.
} 


\section{Jorge Navarro López}

de las necesidades de la mayoría popular, proclamando como estación final al socialismo.

Ciertamente el POS en sus inicios no tuvo un referente práctico, pero cuando se produjo la revolución bolchevique rápidamente fue entendida como la verdadera democracia, principalmente, porque buscaba restituir los derechos sociales y económicos de la mayoría. En cambio, el PC siempre tuvo a su lado la luz (o sombra) de la URSS a la cual comprendió como la expresión política más justa, más democrática. El «mito de Stalin» jugó un papel importante en la configuración política de los comunistas chilenos, tal como lo reconoció en enero de 1990 Teitelboim. Lo suyo también hizo la «dictadura del proletariado». Sin embargo, la insurrección armada y el asalto al poder nunca fueron opciones reales para el PC, excepto en los años de mayor algidez de la PRPM. Durante la mayor parte de su historia, la democracia a la que aspiraban los comunistas era muy similar a la del POS, una que se constituyera en y representara a la mayoría popular.

Así lo estableció también la Conferencia Nacional comunista de junio de 1990, que en sus resoluciones demostraba escepticismo por el curso que tomaban el nuevo gobierno, principalmente respecto a lo que denominaban «presión del continuismo» y que advertían se iba haciendo extensiva en la Concertación bajo la figura de la «democracia de los acuerdos» (cuya base era la moderación de las reformas a la Constitución de 1980 y el mantenimiento de Pinochet como cabeza del Ejército). En esta conferencia comunista se planteó la intención de buscar acuerdos en la izquierda para profundizar la democracia, alianzas que debían convertir al «protagonismo popular en el eje central del avance democratizador». Además, según el PC, la izquierda debía solucionar su crisis demostrando «su disposición para conducir al movimiento popular en la avanzada del tránsito democrático». Tras señalar aquello, planteaban su objetivo estratégico principal: «llevar a cabo en Chile una revolución democrática, popular y nacional, antiimperialista y antioligárquica, basada en la participación activa y en el apoyo de las mayorías del país» ${ }^{59}$.

Setenta y cinco años antes, y tras su primer congreso partidista, el POS aprobó un programa que incluía aspiraciones como leyes de ampliación del marco democrático, supresión del ejército permanente, legislación laboral a favor de los trabajadores (contrato, seguro de salud y desempleo, tribunales laborales, reducción de la jornada, supresión del trabajo infantil y barrios obreros), educación estatal obligatoria, gratuita y laica, abolición de la propiedad privada, nacionalización de ferrocarriles, minería y fuentes de energía ${ }^{60}$. Estos puntos coinciden con el anhelo del PC de una «revolución democrática, popular, antioligárquica y antiimperialista». Paradójicamente, los socialistas lo entendían como parte de un proyecto a futuro, para los comunistas, en cambio, se trataba de volver a conseguir los frutos de una lucha de más de medio siglo. El futuro de unos era el pasado de otros.

\footnotetext{
59 "Conferencia Nacional del Partido Comunista de Chile", op. cit., pp. 52-54.

${ }^{60}$ El Despertar de los Trabajadores, Iquique, 4/05/1915.
} 
Volviendo a los orígenes. La reconfiguración política-cultural del Partido
Comunista de Chile y el rescate de los fundadores (1988-1990)

Precisamente en esta paradoja se fundaba el reconocimiento de los comunistas de sus años como POS. «Son dos fases de un mismo proceso. Ambos son uno solo y responden a una continuidad estricta», declaraba Volodia Teitelboim al entregar las conclusiones de la conferencia de junio de 1990. Con el rescate de la década de acción política del POS, los comunistas esperaban recobrar «en toda su significación la memoria histórica más plena, reivindicando nuestra pertenencia a un partido que nació de las entrañas mismas de la tierra chilena, enarbolando la enseña del socialismo». Y concluía enfáticamente: la bandera del socialismo «no caerá nunca de nuestras manos» 61 .

\section{Conclusión}

El rescate del legado del POS tuvo como principal objetivo dotar a los comunistas de un referente nacional de lucha democrática. El ambiente crítico que enfrentó el PC a fines de los ochenta y comienzos de los noventa estimuló un cambio en los referentes políticos. En este sentido, la experiencia del POS les permitió a los comunistas rescatar su impronta nacional y distanciarse de la tradición bolchevique. Por otro lado, las características del discurso y las luchas de los socialistas del primer cuarto del siglo xx se conectaban con la situación del PC y su aislamiento político setenta años después. La clave estaba en la reconfiguración del concepto de democracia, disputado a los comunistas por el conjunto de la élite política de la transición.

La renovación que llevó a cabo el PC no tomó el rumbo del resto de la izquierda, y si bien se flexibilizaron algunas matrices propias del bolchevismo, el rescate del legado del POS y de Recabarren fue una respuesta al cuestionamiento de si tenía sentido seguir siendo comunista después del fin del comunismo. El proceso iniciado a fines de los ochenta concluyó en 1994, cuando el PC proclamó la tesis de la «Revolución Democrática» o su fórmula para enfrentar la exclusión política y también ideológica. Era una forma de responder a una situación inédita para este partido: no poder representar a los sectores populares en el sistema político. Los cambios estructurales que experimentó Chile bajo la dictadura y que se mantuvieron con los gobiernos de la Concertación (1990-2010), dejaron al PC sin referentes. En el país ya no se habló más de «pueblo», ahora el discurso político convocaba a la «gente».

La trayectoria del PC en los primeros años de la transición debería aportar para evaluar si la reconfiguración de su identidad, que perseguía el rescate del POS, tuvo continuidad y peso entre los comunistas o si sólo fue una respuesta contextual ante un período de crisis. La simbólica celebración de los cien años del PC en 2012 indicaría que sí hubo continuidad. Sin embargo, su tránsito político en las dos décadas anteriores a esta conmemoración plantea ciertas dudas. Por ejemplo, la

${ }^{61}$ El Siglo, Santiago, 10/06/1990. 


\section{Jorge Navarro López}

opción de no levantar un candidato propio para las elecciones presidenciales de 1993, a favor de su apoyo al sacerdote católico Eugenio Pizarro, puede ser un indicador de las dificultades que tenía el PC para reformular su identidad bajo la matriz recabarrenista y obrerista. Así también, su acercamiento e identificación con el régimen cubano, con el zapatismo y con los movimientos anti-sistémicos, revela que a fines de los noventa y principios del nuevo siglo la búsqueda de referentes era todavía un proceso en marcha. Estos elementos, como otros más actuales, invitan a preguntarse sobre la recepción y consolidación de la cultura política de Recabarren y el POS en el PC.

\section{Bibliografía}

Álvarez V., Rolando, “iViva la revolución y la patria! Partido Comunista de Chile y nacionalismo (1921-1926)", Revista de Historia Social y de las mentalidades, 7, vol. 2, 2003, pp. 25-44.

Álvarez V., Rolando, “¿La noche del exilio? Los orígenes de la rebelión popular en el Partido Comunista de Chile”, en Verónica Valdivia, Rolando Álvarez y Julio Pinto, Su revolución contra nuestra revolución. Izquierdas y derechas en el Chile de Pinochet (1973-1981), Santiago, Lom Ediciones, 2006, pp. 101-152.

Álvarez V., Rolando, Arriba los pobres del mundo. Cultura e identidad política del Partido Comunista de Chile entre democracia y dictadura. 1965-1990, Santiago, Lom Ediciones, 2011.

Álvarez V., Rolando, “¿Herejes y renegados?: la diáspora de la disidencia comunista chilena (1989-1994)", Mimeo, 2016.

Andrade, Juan, El PCE y el PSOE en (la) transición. La evolución ideológica de la izquierda durante el proceso de cambio político, Madrid, Siglo XXI, 2012.

Aranda, Claudia y Ricardo Canales, Fundamentos históricos e ideológicos del Partido Obrero Socialista de Chile (1912-1915), Mimeo, 1992.

Artaza, Pablo, Movimiento social y politización popular en Tarapacá. 1900-1912, Concepción, Ediciones Escaparate, 2006.

Bernstein, Serge, "La cultura política”, en Jean-Pierre Rioux y Jean-François Sirinelli (dir.), Para una historia cultural, México D.F., Taurus, 1998, pp. 389-405.

Bueno, Manuel y Sergio Gálvez (Eds.), "Nosotros los comunistas". Memoria, identidad e historia social, Madrid, FIM/Atrapasueños, 2009. 
Volviendo a los orígenes. La reconfiguración política-cultural del Partido
Comunista de Chile y el rescate de los fundadores (1988-1990)

Casals, Marcelo, "La "larga duración” del autoritarismo chileno. Prácticas y discursos anticomunistas camino al Golpe de Estado de 1973", Revista de Historia y Geografía, 29, 2013, pp. 31-54.

Casals, Marcelo, La creación de la amenaza roja. Del surgimiento del anticomunismo en Chile a la «campaña del terror» de 1964, Santiago, Lom Ediciones, 2016.

Drake, Paul e Iván Jaksic (Comp.), El modelo chileno. Democracia y desarrollo en los noventa, Santiago, Lom Ediciones, 1999.

Fernández, Luis Ramiro, Cambio y adaptación en la izquierda. La evolución del Partido Comunista de España y de Izquierda Unida (1986-2000), Madrid, CIS-Siglo XXI, 2004.

Fukuyama, Francis, “¿El fin de la historia?”, Estudios Públicos, 37, 1990, pp. 5-31.

Furet, François, El pasado de una ilusión. Ensayo sobre la idea comunista en el siglo XX, México D. F., FCE, 1995.

Garcé, Adolfo, La política de la fe. Apogeo, crisis y reconstrucción del PCU (1985-2012), Montevideo, Editorial Fin de Siglo, 2012.

Garretón, Manuel A., La posibilidad democrática en Chile, Santiago, FLACSO, 1989.

González M., Sergio, Carlos Maldonado y Sandra McGee, "Las Ligas Patrióticas", Revista de Ciencias Sociales, 2, 1993, pp. 54-72.

Grez, Sergio, Historia del Comunismo en Chile. La era de Recabarren (1912-1924), Santiago, Lom Ediciones, 2011.

Grez, Sergio, El Partido Democrático de Chile. Auge y ocaso de una organización política popular (1887-1927), Santiago, Lom Ediciones, 2016.

Hobsbawm, Eric, Cómo cambiar el mundo, Buenos Aires, Crítica, 2013.

López, Mercedes F., "El anticomunismo argentino entre 1930 y 1943. Los orígenes de la construcción de un enemigo", The International Newsletter of Communist Studies, XXII/XXIII, 29-30, 2016-2017, pp. 71-80.

Maira, Luis y Guido Vicario, Perspectivas de la izquierda latinoamericana. Seis diálogos, Santiago, FCE, 1991.

Massardo, Jaime, La formación del imaginario político Luis Emilio Recabarren, Santiago, Lom Ediciones, 2008.

Millas, Orlando, De O’Higgins a Allende. Páginas de la historia de Chile, Madrid, Ediciones Michay, s/f. 
Millas, Orlando, Memorias, 1957-1991. Una digresión. Volumen IV, Santiago, Ediciones Chile-América CESOC, 1996.

Motta, Rodrigo Patto Sá, Em guarda contra o "perigo vermelho". O anticomunismo no Brasil (1917-1964), Sâo Paulo, Editora Perspectiva, 2002.

Millas, Orlando, "Desafios e possibilidades na apropriação de cultura política pela historiografia", en Rodrigo Patto Sá Motta (dir.), Culturas Políticas na História: novos estudos, Belo Horizonte, Fino Traço Editora, 2009, pp. 13-37.

Moulian, Tomás, Chile actual. Anatomía de un mito, Santiago, Lom Ediciones, 1997.

Muñoz C., Víctor, Cuando la patria mata. La historia del anarquista Julio Rebosio (1914-1920), Santiago, Editorial USACH, 2011.

Navarro L., Jorge, Revolucionarios y parlamentarios. La cultura política del Partido Obrero Socialista, 1912-1922, Santiago, Lom ediciones, 2017.

Pairicán P., Fernando, "La gran crisis: las Juventudes Comunistas defendiendo la identidad en tiempos de transición y renovación democrática, 1989-1992", Izquierdas, 30, Octubre 2016, pp. 124-160.

Peña, Juan Cristóbal, Los fusileros. Crónica secreta de una guerrilla en Chile, Santiago, Random House Mondadori, 2013.

Pérez L., Manuel e Ismael Saz C., "Presentación de la obra”, en Miguel Ángel Cabrera y Juan Pro (coord.), La creación de las culturas políticas modernas, 1808-1933, Madrid-Zaragoza, Marcial Pons Historia-Prensas de la Universidad de Zaragoza, 2014, pp. 9-21.

Pinto, Julio, "Socialismo y salitre: Recabarren, Tarapacá y la formación del Partido Obrero Socialista”, Historia, vol. 32, 1999, pp. 360-362.

Pinto, Julio, "El despertar del proletariado: El Partido Obrero Socialista y la construcción de la identidad obrera en Chile", Hispanic American Historical Review, 86:4, 2006, pp. 707-745.

Pinto, Julio, Desgarros y utopías en la pampa salitrera. La consolidación de la identidad obrera en tiempos de la cuestión social (1890-1923), Santiago, Lom Ediciones, 2007.

Pinto, Julio, Luis Emilio Recabarren. Una biografía histórica, Santiago, Lom Ediciones, 2013. 
Volviendo a los orígenes. La reconfiguración política-cultural del Partido
Comunista de Chile y el rescate de los fundadores (1988-1990)

Pinto, Julio y Verónica Valdivia, ¿Revolución proletaria o querida chusma? Socialismo y Alessandrismo en la pugna por la politización pampina (1911-1932), Santiago, Lom Ediciones, 2001.

Plaza A., Camilo y Víctor Muñoz C., "La Ley de Residencia de 1918 y la persecución a los extranjeros subversivos", Revista de Derechos Fundamentales, 10, 2013, pp. 107 136.

Pudal, Bernard, Un monde défait. Les communistes francais de 1956 à nos jours, Bellecombe-en-Bauges, Éditions du Croquant, 2009

Ramírez Necochea, Hernán, Obras escogidas. Vol. II, Santiago, Lom Ediciones, 2007.

Recabarren, Floreal, La matanza de San Gregorio. 1921: crisis y tragedia, Lom Ediciones, 2003.

Riquelme, Alfredo, Rojo atardecer. El comunismo chileno entre dictadura y democracia, Santiago, DIBAM-Centro de Investigaciones Diego Barros Arana, 2009.

Rojas N., Luis, De la rebelión popular a la sublevación imaginada. Antecedentes de la Historia Política y Militar del Partido Comunista de Chile y el FPMR, 1973-1990, Santiago, Lom Ediciones, 2011.

Samaniego, Augusto y Álvaro Palacios, "Pensando una "perestroika" para la izquierda chilena”, en VV.AA., Crítica y socialismo: una reflexión desde Chile, Santiago, Ediciones CISPO, 1989, pp. 193-217.

Teitelboim, Volodia, "Democracia, socialismo y renovación del PC de Chile", en VV.AA., Crisis y renovación, Santiago, Ediciones Medusa-ICAL, 1990, pp. 203-231.

Urtubia O., Ximena, Hegemonía y cultura política en el Partido Comunista de Chile: la transformación del militante tradicional, 1924-1933, Santiago, Ariadna Universitaria, 2016.

\section{Fuentes}

a. Archivos manuscritos:

- Conferencia Nacional del Partido Comunista de Chile”, Mimeo, junio 1990.

b. Prensa:

- $\quad$ El Despertar de los Trabajadores, Iquique, 1915.

- El Siglo, Santiago, 1989-1990. 
Jorge Navarro López

- $\quad$ La Nación, Santiago, 1988-1990.

- Pluma y Pincel, Santiago, 1990.

Recibido: 17/05/2017

Evaluado: 27/06/2017

Versión Final: 26/07/2017 